Tiina Tambaum

Tallinn University

\title{
Elderly learners in combined-age learning groups picking up on new professional skills*
}

\author{
Osoby starsze uczące się w grupie zróżnicowanej wiekowo \\ zdobywające nowe umiejętności zawodowe
}

\begin{abstract}
Summary. In the study carried out by using qualitative methods, a research instrument for measuring the applicability of principles recommended for the elderly learning in an age-heterogeneous group was created based on geragogy reference sources. The action research of one group showed that most of the principles of geragogy were applied in the study process, although the respective training course was not specifically designed for the elderly. In this combined-age learning group, elderly learners experienced some problems, and recommendations are proposed to solve them.
\end{abstract}

Keywords: elderly learning, geragogy, combined-age learning group.

Streszczenie. W badaniu przeprowadzonym przy użyciu badań jakościowych stworzono narzędzie badawcze do pomiaru zastosowania zasad rekomendowanych dla uczących się osób starszych w grupie zróżnicowanej wiekowo. Narzędzie to powstało w oparciu o źródła odniesienia do geragogiki. Badania w działaniu (action research) przeprowadzone na jednej grupie wykazały, że większość z zasad geragogiki miała swoje zastosowanie w procesie uczenia, mimo że szkolenie nie było skierowane wyłącznie do osób starszych. W tej uczącej się, zróżnicowanej wiekowo grupie, starsze osoby doświadczyły pewnych trudności podczas uczenia się. Niniejszy artykuł ma na celu zaproponować rozwiązania dla owych problemów.

Słowa kluczowe: uczenie się osób starszych, geragogika, zróżnicowana wiekowo grupa ucząca się.

" Text is published previously in Conference Papers in 2012: Jelenc Krašovec, S., Radovan, M. (eds.) (2012). Conference Papers. The Third Conference of the ESREA Network on Education and Learning of Older Adults: Intergenerational solidarity and education of older adults in community, Ljubljana, 19-21 Sept. 2012. Faculty of Arts at the University of Ljubljana, pp. 187-203. 


\section{Acknowledgments}

The author would like to thank Prof. Peeter Normak and the Population and Housing Census team of Estonia. The study was partly supported by European Social Fund grant No. 1.2.0401.09-0070.

Elderly learners have some specific features.

Modern educational sciences have taken the position that a human being is able to and must have the opportunity to learn as long as they live (Maderer \& Skiba, 2006; Findsen, Formosa, 2011, pp. 112-115). Studies have confirmed that the differences both in learners' ability to learn and in their preference of study methods are related to their age (John, 1981; Pincas, 2007; Requejo-Osorio, 2008; Formosa, 2011).

The objective changes affecting the ability to learn fall into four categories: a) senso-perceptive functions (e.g. impairment of vision); b) psychometric capacity (the speed of mental and physical activity decreases); c) concern over worsening memory related to degenerative diseases; and d) impairing fluid intelligence (availability of applying intellectual skills to new situations).

The course of evolution of geragogy underlines that it is also essential to consider the characteristic features of the social and cultural background of the older age group (Battersby, 1985). For example, the elderly value flexible ways of learning combined with the opportunity to act autonomously. Unlike the young learners, the elderly tend to have strong preferences about how to learn (Pincas, 2007).

\section{Joint learning issues}

The academic references and implementation projects in the field of educational gerontology mostly describe learning situations that are specifically organised for groups of elderly learners.

Several studies have referred to the hypothetical need for special training strategy because of elderly learners' participation (Meyer, 1977; John, 1981; Xie, 2007; Echt, Morrell, \& Park, 1998; Cody et al. 1999). Lemieux \& Martinez (2000) say that any educational intervention that is not based on gerontology may cause damage, e.g. teachers behavior in a patronising way that demeans the elderly (Nelson, 2005) or decrease of personal responsibility for its achievement (Formosa, 2002) after an unsuccessful training session. 
Paulo Freire (cited in Requejo-Osorio, 2008) has emphasised that “... the criteria for age evaluation, either for youth or for the elderly, cannot be the calendar. /.../. Physically old but intellectually active people should be provided with development opportunities along with other members of society, especially in the circumstances of ageing society and the increasing need of the eldrely integration into the labour market.

\section{The objective of the study and research questions}

The aim of this qualitative study is to get indicative information on whether and what kind of special attention should be paid to the specific needs of elderly learners in professional training courses, which the elderly attend along with others.

The following questions have been set in the study:

Which geragogy principles can be expected to be applied in adult group training, which are not specifically designed for the elderly?

Which techniques applied in joint learning can support the learning process of the elderly in a joint learning situation based on the study, but which are normally not discussed in geragogy theory?

What kind of problems do elderly learners have in a combined-age learning group and how can they be solved?

\section{Background}

In early 2012, Statistics Estonia carried out the Population and Housing Census. A total of 132 regional managers and 2,200 enumerators were recruited for collecting the data (press). The age of the enumerators attending the training course ranged from 19 to 79 . Statistics Estonia provided training for regional managers who in turn instructed the group of enumerators in their region. All enumerators were given a laptop with a special data entering and map applications and thus their experience in using computers was an important factor in learning new professional skills. To train enumerators for their job, the training materials (Annex 1 ) were prepared.

It was assumed in the training project that all learners are highly motivated to learn. The project did not foresee improving the regional managers' teaching skills who were responsible for carring on trainings for enumera- 
tors. The preparatory work for their training did not involve didactic methods, or taking into account learners' specific features, age-specific included. A five-day training programme for enumerators ended with a two-hour test.

\section{The principles of the design of the learning process and instructional styles}

In the course of working through academic references in the fields of geragogy and educational gerontology (ONLUS; John, 1981, Requejo-Osorio, 2008, Formosa 2011, Pincas, 2007; Nussbaum, 2008), ten categories evolved step by step, which translated into a total of thirty principles of organising the learning of the elderly (Table 1 ).

Table 1. The principles of organising the learning for the elderly

\begin{tabular}{|c|c|c|c|}
\hline & $\begin{array}{l}\text { Category / } \\
\text { Attribute }\end{array}$ & Explanation / Description of the principle & Examples, comments \\
\hline 1. & Flexibility & $\begin{array}{l}\text { The target group of the elderly is not homog- } \\
\text { enous, they have different learning experiences. }\end{array}$ & \\
\hline 1.01 & Pace & $\begin{array}{l}\text { The learner has a possibility to choose their own } \\
\text { pace of learning. }\end{array}$ & \\
\hline 1.02 & Study style & $\begin{array}{l}\text { The learner has a possibility to choose between } \\
\text { the styles of acquiring new material. }\end{array}$ & $\begin{array}{l}\text { reads from materials, listens to } \\
\text { instructor, asks }\end{array}$ \\
\hline 1.03 & $\begin{array}{l}\text { Reinforcement } \\
\text { style }\end{array}$ & $\begin{array}{l}\text { The learner has a possibility to choose between } \\
\text { ways of reinforcing the material learnt. }\end{array}$ & $\begin{array}{l}\text { performing a task, participating } \\
\text { in discussions }\end{array}$ \\
\hline 2. & Diversity & $\begin{array}{l}\text { Learners have different life experiences, which } \\
\text { can be implemented in the study process }\end{array}$ & \\
\hline 2.04 & Sharing & $\begin{array}{l}\text { Learners can share their experiences in life with } \\
\text { others. }\end{array}$ & \\
\hline 2.05 & Usage & $\begin{array}{l}\text { Learners can use their personal experience } \\
\text { during training sessions. }\end{array}$ & $\begin{array}{l}\text { not measured in this study, as } \\
\text { the aim of the training was to } \\
\text { learn a new specialty }\end{array}$ \\
\hline 2.06 & Transformation & $\begin{array}{l}\text { Learners can transform their experience during } \\
\text { training sessions. }\end{array}$ & \\
\hline 2.07 & $\begin{array}{l}\text { Using con- } \\
\text { nections in } \\
\text { learning new } \\
\text { things }\end{array}$ & $\begin{array}{l}\text { Instructor explains new terms and subjects } \\
\text { through the terms and phenomena known to } \\
\text { the elderly. }\end{array}$ & \\
\hline
\end{tabular}


Table 1. The principles of organising the learning for the elderly (continue)

Category / Attribute

Explanation / Description of the principle

Examples, comments

\begin{tabular}{|c|c|c|c|}
\hline 2.08 & $\begin{array}{l}\text { Using } \\
\text { connections in } \\
\text { reinforcing the } \\
\text { material learnt }\end{array}$ & $\begin{array}{l}\text { Instructor reinforces the material learnt by creat- } \\
\text { ing connections between previously learned } \\
\text { material and previous life experience. }\end{array}$ & \\
\hline 3. & Usefulness & $\begin{array}{l}\text { Elderly people want to feel useful and therefore } \\
\text { the material learned should be directly useable } \\
\text { in their life. }\end{array}$ & \\
\hline 3.09 & $\begin{array}{l}\text { The applicabil- } \\
\text { ity of study } \\
\text { content }\end{array}$ & $\begin{array}{l}\text { Training assignments, materials and examples } \\
\text { are directly applicable. }\end{array}$ & \\
\hline 3.10 & $\begin{array}{l}\text { The applicabil- } \\
\text { ity of learning } \\
\text { outcome }\end{array}$ & $\begin{array}{l}\text { The learning outcomes of learners are applied } \\
\text { in life. }\end{array}$ & not measured in this study \\
\hline 4. & Modernity & $\begin{array}{l}\text { The objective of teaching the elderly is to support } \\
\text { their independent coping skills in modern society. }\end{array}$ & \\
\hline 4.11 & Phenomena & $\begin{array}{l}\text { Phenomena that the younger members of the } \\
\text { group are familiar with are explained to the } \\
\text { elderly. }\end{array}$ & \\
\hline 4.12 & Means/tools & $\begin{array}{l}\text { Means/tools that the younger members of the } \\
\text { group are familiar with are explained to the } \\
\text { elderly. }\end{array}$ & \\
\hline 4.13 & Terms & $\begin{array}{l}\text { Terms that the younger members of the group } \\
\text { are familiar with are explained to the elderly. }\end{array}$ & \\
\hline 5. & $\begin{array}{l}\text { Competitive- } \\
\text { ness }\end{array}$ & $\begin{array}{l}\text { The society is characterised by age-based } \\
\text { stereotyping and discrimination. The elderly, and } \\
\text { also all others, may not be aware of it. }\end{array}$ & \\
\hline 5.14 & $\begin{array}{l}\text { Awareness } \\
\text { raising }\end{array}$ & $\begin{array}{l}\text { Both the elderly and all other people are made } \\
\text { aware of stereotyping and discrimination implica- } \\
\text { tions. }\end{array}$ & \\
\hline 5.15 & Fighting & $\begin{array}{l}\text { The implications of age-based stereotyping are } \\
\text { fought against during studies. }\end{array}$ & \\
\hline 5.16 & Conduct & $\begin{array}{l}\text { The conduct during studies is characterised } \\
\text { by equal treatment of both the young and the } \\
\text { elderly. }\end{array}$ & $\begin{array}{l}\text { The elderly are not given any } \\
\text { privileges; their actions are not } \\
\text { restricted. }\end{array}$ \\
\hline 6. & $\begin{array}{l}\text { Activeness } \\
\text { and independ- } \\
\text { ence }\end{array}$ & Elderly learners tend to act autonomously. & \\
\hline 6.17 & Activeness & $\begin{array}{l}\text { Learners are given an opportunity to be active } \\
\text { individuals in the study process who take } \\
\text { responsibility for their learning. They are guided to } \\
\text { be active in their future life. }\end{array}$ & \\
\hline
\end{tabular}




\section{2 | Tiina Tambaum}

Table 1. The principles of organising the learning for the elderly (continue)

\begin{tabular}{|c|c|c|c|}
\hline & $\begin{array}{l}\text { Category / } \\
\text { Attribute }\end{array}$ & Explanation / Description of the principle & Examples, comments \\
\hline 6.18 & Autonomy & $\begin{array}{l}\text { Learners are given an opportunity to be autono- } \\
\text { mous individuals during studies. }\end{array}$ & \\
\hline 7. & Security & $\begin{array}{l}\text { Elderly people need encouragement, as they } \\
\text { tend to regard their existing knowledge insuf- } \\
\text { ficient for training and their intellectual abilities } \\
\text { required for learning have impaired with age. }\end{array}$ & \\
\hline 7.19 & $\begin{array}{l}\text { Encourage- } \\
\text { ment }\end{array}$ & Learners are encouraged during studies. & \\
\hline 7.20 & $\begin{array}{l}\text { Avoiding } \\
\text { intimidation }\end{array}$ & Intimidating people is avoided during studies. & $\begin{array}{l}\text { excellence is not required; } \\
\text { introduction of what comes } \\
\text { next }\end{array}$ \\
\hline 7.21 & $\begin{array}{l}\text { Avoiding } \\
\text { isolation }\end{array}$ & $\begin{array}{l}\text { It is made sure that people do not end up in } \\
\text { isolation during studies. }\end{array}$ & they are encouraged to talk \\
\hline 7.22 & Respect & $\begin{array}{l}\text { Respect for individuals is demonstrated during } \\
\text { studies. }\end{array}$ & \\
\hline 7.23 & Kindness & $\begin{array}{l}\text { Human kindness in regard to elderly learners is } \\
\text { demonstrated during studies. }\end{array}$ & $\begin{array}{l}\text { using names when addressing } \\
\text { them, eye contact }\end{array}$ \\
\hline 8. & $\begin{array}{l}\text { Sense of suc- } \\
\text { cess }\end{array}$ & $\begin{array}{l}\text { Elderly people get tired quicker and feel that it } \\
\text { was easier to learn at a younger age. }\end{array}$ & \\
\hline 8.24 & Praise & People are made aware of their progress. & \\
\hline 8.25 & $\begin{array}{l}\text { Getting over } \\
\text { tiredness }\end{array}$ & $\begin{array}{l}\text { Group and instructor react positively to being } \\
\text { tired. }\end{array}$ & \\
\hline 9. & Sustainability & $\begin{array}{l}\text { Teaching the elderly must support individual's } \\
\text { willingness and ability to continue learning and } \\
\text { self-development. }\end{array}$ & \\
\hline 9.26 & Metacognition & $\begin{array}{l}\text { The techniques of developing people as learners } \\
\text { are taught during the training. }\end{array}$ & self-reflection \\
\hline 9.27 & Self-help & $\begin{array}{l}\text { The techniques of restoring learning capability } \\
\text { are taught to the elderly during the training. }\end{array}$ & $\begin{array}{l}\text { techniques of memory training, } \\
\text { recovering from tiredness }\end{array}$ \\
\hline 10. & Enjoyability & $\begin{array}{l}\text { Learning is easy, if led by person's own inquisi- } \\
\text { tiveness and the environment is pleasant. }\end{array}$ & \\
\hline 10.28 & Inquisitiveness & $\begin{array}{l}\text { The inquisitiveness of learners is stimulated } \\
\text { during studies. }\end{array}$ & posing problems \\
\hline 10.29 & $\begin{array}{l}\text { Informal } \\
\text { atmosphere }\end{array}$ & $\begin{array}{l}\text { Entertaining and informal atmosphere is created } \\
\text { during studies. }\end{array}$ & \\
\hline
\end{tabular}




\section{Method}

An action research was conducted. The author observed the classroom work of one group (32 learners, including five elderly learners) during one training day (7 hours). All training materials were elaborated. Semi-structured interviews were carried out with the trainer and two elderly learners after the training programmes as well as after the first week of actual census work. Correlations between the age of all Estonian enumerators and their exam result were calculated in order to set the study results against a more general perspective.

The tasks given by instructor and his activities as well as the activities of five elderly learners (M65, F63, F61, F61, M68) were registered in an observation protocol. Additionally, the activities of learners sitting near the elderly were also registered. A separate note was made for situations, where the activities or reactions of the elderly differed from the activities of the group in general.

The observation protocol and interview protocols were analysed using the content analysis method. In the course of analysing, the content of the observation protocol was divided into such action units, which could be correlated with at least one theoretical attribute from the list of the categories and attributes in Table 1, taking into account that theoretical attributes are not mutually exclusive.

The values of one or several attributes were linked to each action unit. If the attribute had a negative connotation, the occurrence of the attribute was marked with a minus sign (e.g. -6.17).

In order to reduce the subjective influence of the author, a person not involved in the study, analysed the observation protocol of the first hour of training. The results were compared and the differences were settled so that both analysers were satisfied.

The occurrence of the values of attributes was recorded in a frequency table (Appendix 2).

During the two interviews conducted with the instructor and two elderly learners, three types of questions were asked: a) feedback on training; b) opinion on personal coping and problems faced; and c) suggestions what would meet the needs of elderly learners better. The author made notes during the interview in her computer.

The answers and statements of interviewees were linked to the action units of the observation protocol. 
The author had access to all training materials what were not a direct research object of the study but used for specifying purposes.

\section{Results}

\section{New attributes revealed in the interviews}

In the interviews with the elderly two new categories were revealed - quality and comfort - and one new attribute - meaningful use of time.

The quality of the knowledge provided, which would give an elderly learner a chance to feel confident when starting work, was touched upon four times during the interviews.

EW: "In our group the teacher said that write it down, when he did not know. He found it out. Thanks to it you would now want to take this job."

The issue of comfort was raised in connection with three factors - cosy environment, human environment, and convenience of using materials. The room and the human environment were expected to be cosy in the sense of supporting learning and not in the sense of feeling relaxed.

The issue of training materials was raised relatively often and only in the negative context in the interviews. The elderly interviewed gave five recommendations in connection with training materials.

1) Tasks should not be laid out so that a new task begins at the bottom of the page and continues on the turn of the page.

2) Only one resource should be used for doing one task. If the task is in a workbook, it should be possible to solve it on the same page or it should be possible to read it without turning the page.

3) There must be enough free space for taking notes in the materials.

4) Tasks should not be too long or unstructured as this does not support remembering.

5) The materials and tasks need to be provided in the way which is directly related to real-life situations in which the knowledge learnt is going to be used.

The 'Applicability of study content' attribute occurred during the observation and interviews 13 times in positive connotation and 8 times in negative connotation. The high share of negative assessments proves that the elderly expect concreteness while learning.

Most of the text exercises in the enumerators' training course were biography-based (case studies), while in reality the life story of the person enumerated was often revealed in the course of asking actual questions. In 
addition the training was exceptional because of dummy addresses use in the exercise that caused problems that do not occur if real addresses are used. The interview with the instructor confirmed that the fictional date used in the exercise created much confusion.

The new attribute - meaningful use of time - was related to the one of the compulsory part training. The programme of each training day included watching an instructional video. Both the observation and the interviews with the elderly indicated that elderly people felt inner opposition both towards this kind of dictated content and pace as well as their passive role.

This result supports John's (1981) warning about using films. John argues that if a clip is too long, it would be difficult to keep elderly learners attentive and recommends that clips should last up to 10 minutes. However, in this study, the reason for dissatisfaction was said to be unreasonable usage of time and not tiredness.

\section{Attributes not occurring in the study}

There were two attributes that did not occur during the training sessions or during the interviews. First, the training did not address stereotyping or discrimination instances. The group did not discriminate the elderly although on the first day of training there were plenty of grounds for doing it because of their inadequate computer skills.

No situations occurred where the fact that learners might be tired was openly responded to. The interviews indicated that the training sessions were exhausting to the elderly, but both interviewees considered it normal and did not expect special attention or support. On the other hand they were thankful for tips that helped them stay attentive.

EW: "Just imagine, the instructor taught us what we should do to rest our eyes. We were doing exercises!"

Thus, in the context of the given study, it may be suggested that it would be wise to present self-help techniques separately from the situations where they are actually needed. This way learners can themselves decide whether to use them without being influenced by others.

The same way as no individual attention was paid to the moments of weakness, nobody was directly praised during the observation day. The 'Praise' attribute in the 'Sense of Success' category occurred 8 times but so that the members of the group could themselves realise that they had made progress. 


\section{Occurrence of theoretical categories and attributes}

\subsection{Learning pace and styles}

All attributes of the 'Flexibility' category occurred frequently, both in a positive and negative way. Only possibility which indicated no negative values was the freedom to choose among the ways of reinforcing the material learnt.

EW: "I watched the video at home in advance while completing the assignment and it was good that I watched it."

The observation and the interviews gave almost equal positive and negative results $(9 ;-8)$ in terms of the pace of training. The whole training was divided into parts with fixed duration. The interview with the instructor revealed that in this group in doing the exercises in computers, the pace was chosen after the slowest learners (the elderly). Despite adjusting the pace according to the elderly, the elderly learners observed nevertheless felt that they had to rush while working in the group.

In the group observed, taking notes during open discussions was clearly a specific feature of the elderly in comparison with the non-elderly (among the elderly 13 times out of 38; among the non-elderly 3 times out of 38).

When the learners did the exercises in their computer, an assistant instructor showed the course of the solution on a big screen based on the pace of learners. On one instance, information was displayed on the screen, which could be learned only from the screen. One elderly learner, who generally did not observe the screen, changed spectacles at that moment, watched the screen and took notes. This incident shows that if an elderly learner has to keep an eye on their computer screen, printed instructions, the screen at a distance, etc., it may be physically challenging to them.

\subsection{Security and changing habits}

Similarly to the 'Flexibility' category, the 'Security and closeness' category was represented with all its attributes in the empirical material.

The instructor of the training group observed formulated principles that ruled out negative feedback: "it's OK to know and it's OK not to know". Before every open discussion or when the room got too noisy during independent work, the instructor raised their hand and waited until all learners had also raised their hands to indicate that they were ready to finish their conversations and listen. This way everyone who wanted to say something was automatically in the centre of attention without having to assert themselves. 
EW: "Our group was super, very super group! I tend to rarely speak up during training sessions, but in this group even I dared to ask a question when I didn't understand."

The sense of security was negatively affected by an incident in the beginning of the training week. The printed training materials were handed out to learners already four days before the training session. Both elderly learners interviewed began to independently work on the instruction. As it was very complex and bulky, they got into a dead end.

This incident indicated that if training materials are handed out before the studies begin, it would be useful to also add an explanation on how the studies are designed and what the purpose of delivering the instructions is. The interviewed showed very clearly that elderly learners, who perceive that they may have some difficulties learning in a mixed group, do additional work at home. To support learners' faith in themselves, this additional work should also be instructed and meaningful.

The 'Diversity' category was represented in the empirical data with four attributes, most frequently with the opportunities to share experience and transform experiences. As for the latter, it occurred in some occasions in the transformation of the learning experience of the elderly and in the fight accompanying changing one's habits.

EW: "I was used to a big computer where there's a separate section for numbers on the keyboard. I couldn't finish the tasks on first days, as the computer was strange to me."

When enumerators were recruited, the applicants were required to have computer skills. The instructor described however, how different the level of these elderly "skilled users" actually was. Also, in the first week of the training the instructor had to give individual advice to mainly elderly learners on how to use the Outlook mailbox after training sessions. Although all learners had used e-mail before, the elderly were not able to identify the functions of the new e-mail environment on their own. The instances described show that the skills older people have tend to be related to a specific tool and when the tool is changed, they will have to learn the skills anew.

\section{Exam results}

The training course ended with a test. Test-takers were allowed to use all materials. The maximum possible score was 70 points. 
The author of the study had access to the data on all test-takers' year of birth and their test results. The test was taken by 1,561 people. The age groups of test-takers, the arithmetic mean of the results of age groups and the standard deviation in results have been presented in Table 2 .

Table 2. Exam results of all enumerators by age groups

\begin{tabular}{|c|c|c|c|}
\hline Age group & No of people & Average test result & $\begin{array}{c}\text { Standard deviation in } \\
\text { results }\end{array}$ \\
\hline Under 20 & 3 & 56,83 & 12,05 \\
\hline $2-29$ & 285 & 55,98 & 8,06 \\
\hline $30-39$ & 313 & 56,13 & 7,35 \\
\hline $40-49$ & 388 & 55,97 & 7,61 \\
\hline $50-59$ & 353 & 53,42 & 8,34 \\
\hline $60-69$ & 196 & 51,7 & 8,51 \\
\hline $70-79$ & 23 & 49,73 & 8,41 \\
\hline
\end{tabular}

The correlation between the age and the results of all test-takers was 0.19 .

The comparison of two age groups (30-39 and 60-69) indicated that the difference in their average result (56.13 and 51.7) is significant (the standard deviation in the differences of an age group is 0.74 ; characteristic $\mathrm{Z}$ is 6.02 and confidence level is 1 ).

\section{Conclusions}

The action research indicated that almost all proposed general principles of geragogy were implemented in the group training of adults, which was not specifically designed for the elderly. The elderly observed, who were in their 60 s, did well at the training and both they and other learners of the same age passed the exam.

On the other hand, however, the study highlighted some factors in relation to the elderly that were not satisfactory and which organisers of adult training programmes should take into account in planning mixed group training courses.

The elderly observed showed signs of tiredness, and the study process was particularly exhausting to their eyes. It is important to note, however, 
that the issue of tiredness was not addressed at all in the prepared training programme and instructors' training programme. In the group observed the techniques of fighting tiredness were taught in the course of other training activities and every learner decided themselves whether to use them without being influenced by others.

Conclusion 1. In preparing training courses attended by elderly learners it is advisable to systematically address the techniques of maintaining and restoring the ability to learn and take it into account in planning the time schedule of a training course.

In addition to categories of theoretical framework, two new categories occurred in the training observed. These categories were quality and comfort. The quality requirement was referred to first and foremost in the context of the knowledge provided. The high quality of the knowledge in a situation where they had to start using the knowledge independently at once gave elderly learners necessary confidence.

Comfort was seen in terms of cosy room and human atmosphere that would support learning as well as convenient use of training materials. Compared to the non-elderly, elderly learners took significantly more notes. As there was no enough space provided for notes in printed materials, the notes elderly learners wrote on a piece of paper formed an additional resource. This way they had to simultaneously use three or four resources at one time. This kind of 'sweating' slowed down their progress and was uncomfortable.

Conclusion 2. The supportive materials of training courses attended by elderly learners should be designed so that not more than a couple of resources (manageable with two hands, visible with one pair of glasses) are to be simultaneously used for solving a training task by taking also into account that the elderly wish to facilitate their learning by taking notes.

Usefulness-category of the theoretical framework was complemented by the attribute 'time was spent meaningfully'. Watching videos together in the classroom seemed like sitting passively to the elderly learners. The elderly learners, who were also willing to give a voluntary contribution to their studies at home (feeling as if they have to make an extra effort), thought it natural that passive forms of learning are not used in group work. One interviewee referred to a waste of time also when stating that the texts of exercises were too long to read in the classroom.

Conclusion 3. In training programmes of professional skills attended by elderly learners, passive forms of learning can be left for home assignments and only active forms of learning are to be used in classes. 
This study showed, how the impairing ability to adapt to and react to new situations (fluid intelligence) is expressed in training situation. Every learner got a laptop computer, which for most of them was probably different from the one they had got used to at home or at work. Elderly learners were inhibited by differences on the tool, so they needed more time to reach the stage where the computer did not interfere with mastering new substantial skills.

Conclusion 4. For the elderly, newly acquired skills could be related to specific tools used for implementing these skills. Thus computer skills mean knowing how to use one specific type of computers and softwares. It is essential to take this fact into account in setting the prerequisites for attending trainings and in planning the first stage of the training.

The elderly interviewed in this study were very satisfied that all printed materials were delivered to them four days before the training as this way they had an opportunity to work them through on their own. On the other hand, it was not explained how to use the delivered materials.

Conclusion 5. If training materials are delivered before the sessions starts, they should be complemented with instructions on how to independently use the materials and how they should not be used. In Estonian, this stage of the training of the elderly can be called eelisõpe - meaning that learning takes place before the training itself starts and it gives the learner at least some psychological advantage.

One specific feature emerged that should either be confirmed or contested in the following research studies. Do elderly learners have the greater willingness to do additional homework before and during the training. If this hypothesis is confirmed, it can be used in designing the training in general.

\section{Bibliography}

Cody, M. J., Dunn, D., Hoppin, S., \& Wendt, P. (1999). Silver surfers: Training and evaluating Internet use among older adult learners. Communication Education, 48, 269-286.

Doreen K, Baringer, Amanda L. Kundrat, John F. Nussbaum, Instructional communication and older adults, pp. 543-560 (562) [w:] Nussbaum, J. F., Coupland, J. (eds.) (2008). Handbook of Communication and Aging Research. Taylor and Frances e-Library. 
Echt, K. V., Morrell, R.W., \& Park, D. C. (1998). Effects of age and training formats on basic computer skill acquisition in older adults. Educational Gerontology, 24, 3-25.

Findsen, B., Formosa, M. (2011). Lifelong Learning in Later Life. A Handbook of Older Adult Learning. Sense Publishers.

Formosa, M. (2002). Critical Gerogogy: developing practical possibilities for critical educational gerontology. Education and Ageing, Volume 17, Number 1.

John, M. T. (1981). Skills for teaching the elderly subculture. Educational Gerontology, 6:2, 151-164.

Language Course Teaching Methods for Senior Citizens. Grundtvig 1.1. (Grundtvig Training Courses) Content structure for Analysis and conceptual framework. Workpackage 2 under the supervision of Città della Scienza S.c.p.a. - ONLUS, Employment and Training Department

Lemieux, A., Martinez, M. S. (2000). Gerontology beyond words: a reality. Educational Gerontology, 26:5, 475-498.

Maderer, P., Skiba, A. (2006). Integrative Geragogy: Part 1: Theory and Practice of a Basic Model. Educational Gerontology, 32: 125-145.

Meyer, S. L. (1977). Andragogy and the Aging Adult Learner. Educational Gerontology, 2 (2), 115-12.

Nelson, T. D. (ed.) 2005. Ageism. Blackwell Publishing Ltd.

Pincas, A. (2007). How do mature learners learn? Quality in Ageing - Policy, practice and research. Vol 8, issue 4; pp. 28-33 Pavilion Journals, Brighton.

Requejo-Osorio, A. (2008). The learning of the elderly and the profile of the adult educator. Convergence, Volume 41, Number 2-3, 2008, pp. 155-172.

Statistics Estonia (2012). Training materials for enumerators.

Xie, B. (2007). Information Technology Education for Older Adults as a Continuing Peer-Learning Process: A Chinese Case Study. Educational Gerontology, 33 (5), 429-450.

\section{Appendix 1. Training materials prepared by Statistics Estonia}

For enumerators:

Exercises (A4, 34 pp.)

Enumeration instruction (A4, 174 pp.)

Methodological video lectures

- Using a laptop computer

- Using the map application

- Introduction to filling in questionnaires

- Filling in questionnaires (household, individual, housing questionnaires) 


\section{2 | Tiina Tambaum}

- The rights and responsibilities of enumerators

Video exercises

1. Example of enumeration in the context of a building in town

2. Example of enumeration in the context of building in the rural area Enumerators' safety plan (PP slides)

Rules of conduct and interaction (PP slides)

Enumeration in institutions (PP slides)

For regional managers:

Regional manager's instruction

Right answers

Instructions for special cases (A4, $10 \mathrm{pp}$.)

\section{Appendix 2. The frequency table on the occurrence of attributes}

Total of positive assessments (interview and observation)

\begin{tabular}{|l|c|c|}
\hline \multicolumn{1}{|c|}{ Category name } & $\begin{array}{c}\text { Attribute } \\
\text { code }\end{array}$ & $\begin{array}{c}\text { Number of } \\
\text { occurrences }\end{array}$ \\
\hline Attribute description & 29 & 25 \\
\hline Entertaining and informal atmosphere was created & 2 & 22 \\
\hline Choose the style of acquiring new material & 3 & 16 \\
\hline Choose the style of reinforcing the material & 9 & 13 \\
\hline Tasks, materials, examples are related to real life & 4 & 12 \\
\hline Opportunity to share personal experience & 19 & 12 \\
\hline Learners are encouraged & 1 & 9 \\
\hline Opportunity to choose one's own pace of studying & 22 & 9 \\
\hline Respect for other people is demonstrated & 18 & 8 \\
\hline Autonomous in studies and in the future & 24 & 8 \\
\hline Progress is praised and acknowledged & 21 & 7 \\
\hline Ending up in isolation is avoided & 16 & 6 \\
\hline The young/the elderly are treated equally & 20 & 6 \\
\hline
\end{tabular}




\begin{tabular}{|c|c|c|}
\hline Category name & $\begin{array}{c}\text { Attribute } \\
\text { code }\end{array}$ & $\begin{array}{l}\text { Number of } \\
\text { occurrences }\end{array}$ \\
\hline Intimidation is avoided & 26 & 6 \\
\hline Metacognitive techniques were taught & 6 & 5 \\
\hline Transform one's experience & 17 & 5 \\
\hline Active in studies and in the future & 34 & 5 \\
\hline Quality of content & 8 & 4 \\
\hline Reinforces through relating to previous life experience & 12 & 4 \\
\hline New tools were introduces & 11 & 3 \\
\hline Novel phenomena were explained & 27 & 3 \\
\hline Self-help techniques were taught & 28 & 3 \\
\hline Inquisitiveness was stimulated & 30 & 3 \\
\hline Creates an entertaining atmosphere themselves & 23 & 2 \\
\hline Human kindness is demonstrated & 31 & 2 \\
\hline Cosy environment & 35 & 2 \\
\hline Cosy human environment & 7 & 1 \\
\hline Explains terms through links & 33 & 1 \\
\hline Time was used meaningfully & 13 & 1 \\
\hline Terms new to the elderly were explained & 5 & 0 \\
\hline Use one's own experience & 10 & 0 \\
\hline Opportunity to implement the learning outcome & 14 & 0 \\
\hline Stereotyping is pointed out & 15 & 0 \\
\hline Implications of stereotyping are fought against & 25 & 0 \\
\hline Being tired is positively reacted to & 32 & 0 \\
\hline
\end{tabular}




\section{4 | Tiina Tambaum}

Total of negative assessments (interview)

\begin{tabular}{|l|c|c|}
\hline \multicolumn{1}{|c|}{ Attribute description } & $\begin{array}{c}\text { Attribute } \\
\text { code }\end{array}$ & $\begin{array}{c}\text { Number of oc- } \\
\text { curences }\end{array}$ \\
\hline Choose the style of acquiring new material & -2 & 11 \\
\hline Opportunity to choose one's own pace of studying & -1 & 8 \\
\hline Tasks, materials, examples are related to real life & -9 & 8 \\
\hline Convenient materials & -32 & 5 \\
\hline Active in studies and in the future & -17 & 4 \\
\hline Learners are encouraged & -19 & 3 \\
\hline Opportunity to share personal experience & -4 & 2 \\
\hline Being tired is positively reacted to & -25 & 2 \\
\hline Cosy environment & -31 & 2 \\
\hline Time was used meaningfully & -33 & 2 \\
\hline Explains terms through links & -7 & 1 \\
\hline Entertaining and informal atmosphere was created & -29 & 1 \\
\hline Cosy human environment & -35 & 1 \\
\hline
\end{tabular}

